MACIEJ CZARNECKI

ANNA STAROSTA

\title{
Two Faces of Anti-crisis \\ Management: from \\ Definitions to Concepts
}

\section{Introduction}

Issues related to crisis in a company, although present in literature on management for a long time, still remain unexplained to a great extent. It seems legitimate to say that in the context of economic crash of 2008, connected with the outbreak of financial crisis in the United States followed by debt crisis in several countries of the Euro zone, the subject has become more important than in the years of relatively stable growth of the world economy. In that context, anti-crisis management is becoming more and more significant. Studying the subject literature leads to the conclusion that this concept, although present for many years in literature concerning management, is understood in a number of different ways. The aim of the authors of this work is to systematize the approaches to anti-crisis management. For that purpose, they start with approaches to understanding the very nature of crisis (the definition of crisis).

Ph.D. Maciej Czarnecki Wroclaw University of Economics M. Sc. Anna Starosta Poznan University of Economics

\section{Approaches to the nature of crisis}

The term 'crisis' originates in Greek, from the word "krino" meaning the ultimate 
resolution. It was identified with the sense of uncertainty, break and seeking rescue. The origin of the term 'crisis' can also be found in Latin, where "Crisi" meant the critical, culmination point (Gryz and Kitler 2007, pp. 10-11). The Polish dictionary of foreign words defines crisis as a turning point, the period of radical change or the decisive point (Stownik wyrazów obcych 2000, p. 617). So the term means a decisive moment or point in time followed by change, or a decision situation leading to such a moment (Kral, Zabłocka-Kluczka 2003, pp. 17-18). J.M. Ogrizek and M. Guillery (quoted in: Murdoch 2003, p. 11)claim that the concept of crisis comes from medicine, where it refers to a condition which can either improve or deteriorate. Apart from interpreting crisis as a critical point or a time of change, it can also be defined as (Walas-Trębacz, Ziarko 2011, pp. 17-18):

- a difficult situation - either one occurring at the moment or one which is to happen in the future; it is usually negative and perceived as an anomaly disturbing typical processes,

- instability, or an unstable situation preceding an essential change,

- a situation constituting a threat to normal (efficient, effective) functioning, with a danger of violating values, norms and objectives of the organization and its members,

- a decisive moment - a point in time at which it is resolved whether a given situation will change or not.

Crisis can be discussed from many perspectives (Dąbrowski 2002/2003, p. 31):

- medical - crisis is identified with the moment of sudden change, or of finding the causes of the disease which can have either positive and negative results,

- psychophysical - directly connected both with mental and bodily disorders; then crisis is understood as a "deep problem"; R. Wróblewski (2010, p. 50) perceives crisis as a culmination of conflicts in different areas of life. Conflicts are an integral part of social life, and crises constitute a threat to the interest of the community,

- cosmopolitical - crisis is perceived as a change from heteronomic state to autonomic one,

- epistemologic - crisis is related to the impossibility of synthesizing knowledge,

- economic - crisis is understood as poor economic condition in the macroeconomic scale, a crush of economic growth, a substantial disturbance of economic equilibrium and regression in the development of a state (Stownik wyrazów obcych 2000, p. 617).

The approach which can serve as a starting point for more profound considerations is the systemic one. An organization is regarded as a set of 
mutually related units which affect and determine the success of the entirety. A system may be either in static equilibrium (stability) or dynamic equilibrium (instability). Social organizations are complex systems which are always in a quasi-stable state. It means that at least one element of the system is in a transition period (understood as a period in which the system undergoes transformation or its operational indices undergo qualitative change). All the transition periods can be divided into three groups (Krzakiewicz 2008, pp. 57):

- homeostatic - when changes affect the system's functioning but do not change its structure (they can be either positive or negative),

- innovative - in this case, changes affect the structure and subsystems (positive and negative),

- bifurcation - concerning intensified changes which affect the system's behaviours and structure; a system can be deemed in crisis when the changes causing threat to the system's functioning intensify.

Transition periods are part of the system and result in changes of trends in their development. If the internal potential of the organization finishes, or if external factors occur, transition periods are called critical periods (crises). Changes in trends equal the organizational life cycle and result from changes in transition periods. Upon the change of the periods, crisis symptoms either increase or are reduced (Krzakiewicz 2008, pp. 57-58).

Subject literature presents several divisions of definitions of crisis. They mostly concentrate on perceiving crisis as:

- a process (Wieczerzyńska 2009),

- a process and a decision situation (Urbanowska-Sojkin 1999, pp. 27-36; Łuczak 2003, pp. 115-125), where crisis in the meaning of process (involving cause and effect relationships between events) is understood as a boundary between constructive and destructive phases, and in the context of a decision situation (understood as a problem, difficulty in the enterprise functioning) is related to short decision-making time, unpredictability and fear resulting from uncertainty. In that meaning, crisis id perceived as a change, surprise and uncertainty (Herman 1963, quoted in: Wawrzyniak 1984, pp. 58-59),

- a stage of organizational life cycle and a decision situation (Zelek 2003, pp. 31-46).

According to the authors of this publication, the systemic approach is the starting point for interpreting crisis from two perspectives: the dynamic (processual) and static one (crisis understood as a specific state). 


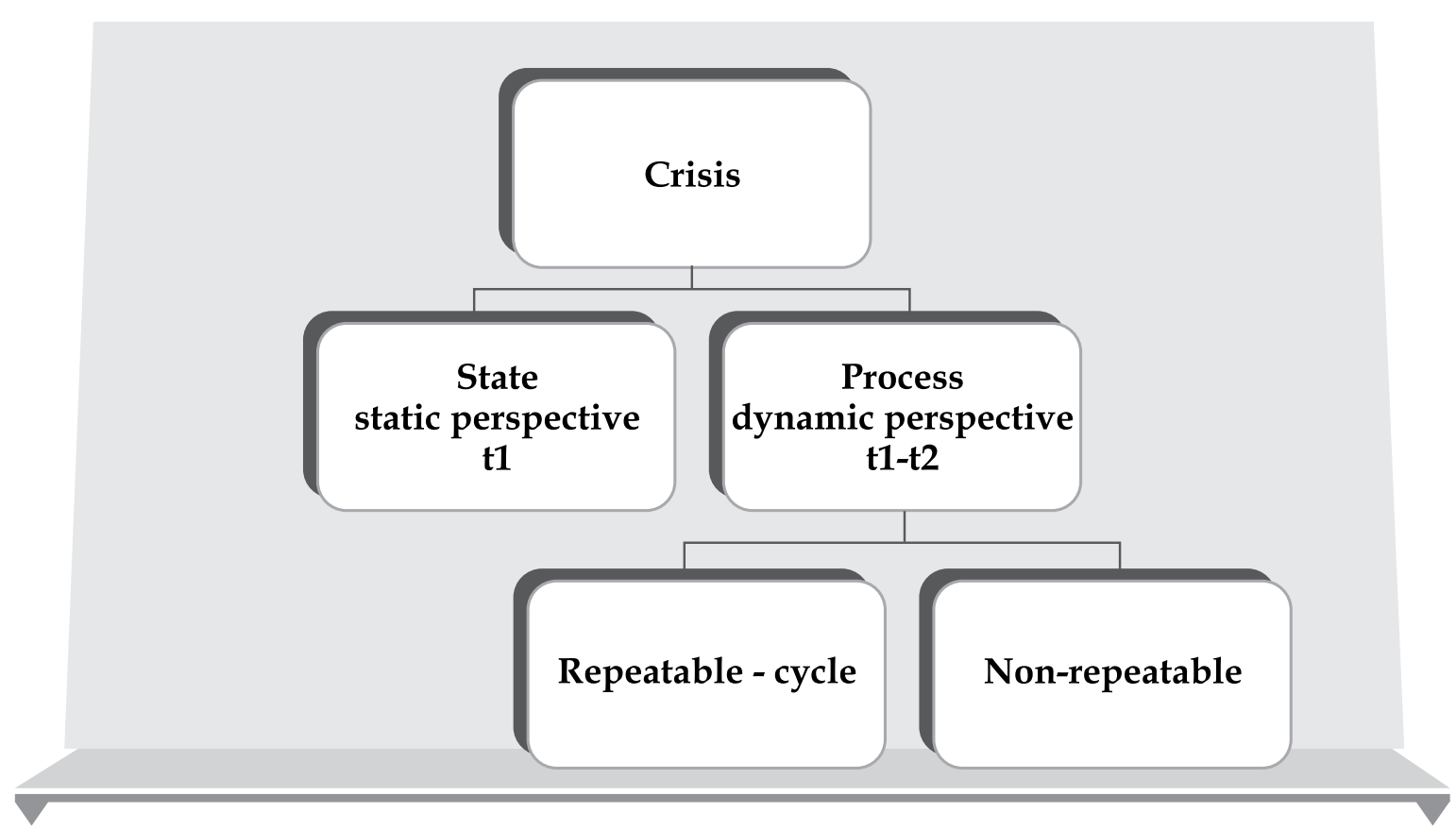

Figure 1. Approaches to defining crisis

Source: own study

The processual approach involves the necessity to consider cause and effect relationships between the events which make destructive and constructive stages. Two kinds of definition can be distinguished in this approach: ones which present crisis as a repeatable cycle (a process of successive events occurring in a specific period; Zimniewicz 1990, p. 223) and ones which emphasize its lack of repeatability.

The process stages are taken into consideration when presenting developmental concepts of companies. It is a group of definitions which presents crisis as a repeatable phenomenon. One of the most popular concepts involving crisis as the end of a specific developmental stage is the concept of development through crises. It was presented by L.E. Greiner (1998, pp. 56-57), who emphasizes the significance of internal causes. Each stage begins with stable and evolutional growth and ends with revolutionary organizational changes which are the fundament of functioning in the next stage. Crises of leadership, autonomy and control (decentralization) are mentioned in this concept. It is worth adding here that L.E. Greiner's model, although probably the most recognizable and most often quoted in literature concerning 
organizational growth and development, is one of many models based of organizational life cycle. The authors of those models basically assume that the phases of organizational life cycle generally occur in a predictable order (Davidsson, Achtenhagen, Lucia 2005). It is hard to determine the exact number of proposed growth models based on the organizational life cycle concept. Phelps et al. mention 33 such models (Phelps, Adams, Bessant 2007, p. 5), whereas J.D. Levie and B. Lichtenstein (2010, p. 324), 104 models. This trend had been popular in literature until the end of the 1990s (cf. e.g. Kazanjian, Drazin 1989; Hanks, Watson, Jansen, Chandler 1994; Davidsson, Achtenhagen, Lucia 2005, etc.); later, the number of publications on that subject dropped considerably. P. Davidsson, L. Achtenhagen and N. Lucia (2005) are of the opinion that the drop was caused by excessive critique which "seems to have led not to better research but to no research at all in this stream more recently". Hence, it is undoubtedly true that "this is unfortunate because it represents the type of knowledge ... managers typically need" (Davidsson, Achtenhagen, Lucia 2005, p. 2), and "managerial science definitely has practical inclination and depends on usefulness for managers" (Czakon 2011, s. 60). The objections scholars pose to these models are their linearity, sequentiality, determinism and invariance, as well as the fact that they have no empirical support; moreover, they claim the comparison of organizations to organisms is inappropriate and particular models are inconsistent with each other (Phelps, Adams, Bessant 2007, pp. $2,4)$. However, studies of the models seem to lead to the conclusion that the above-mentioned faults were characteristic of earlier models (published, more or less, until the early 1980s); most of the later models are to a great extent free from such faults. It is worth mentioning that L.E. Greiner (1998) presents the view that the phenomenon of crises is a positive one in the development of an organization. It is so because it constitutes a good platform for revolutionary organizational changes which could not occur otherwise: the managers would have no determination to execute such profound changes, mainly due to the risk accompanying revolutionary changes and natural resistance to such changes. It is good to mention that this view is not shared by all authors of models based on organizational life cycle. Although they indicate the occurrence of similar problems in the course of development of an enterprise, still they not always use the word "crisis" to describe turning points. They prefer to stick to the statement that problems encountered during growth may (but - as has already been mentioned - do not have to) assume the proportion of crisis (cf. e.g. L. Steinmetz (1969), who uses the word "crisis" only once in his work, later using expressions such as "problems of growth" or "pains of growth", or J. C. Aplin 
and R.A. Cosier (1980), who write about organizational phenomena which can lead to a crisis of control).

Models concentrated on "problems encountered in the course of growth" are an alternative to models based on organizational life cycle. They disregard the number of stages in the life cycle of the organization and their sequence. They concentrate on indicating "typical" problems related to organizational growth and their early detection. What is important is not what developmental stages an enterprise is to undergo in a particular period but the fact that a stable development period based on a consistent success formula will definitely be followed by certain predictable problems. They may have the features of a crisis, and overcoming them will allow to develop a new success formula and further development (Bełz 2011). Such an approach to crises, then, makes the authors of the work include them in the group of definitions understanding crises as nonrepeatable from a dynamic perspective.

The definition presented by M. Porada-Rochon (quoted in: Walas-Trębacz, Ziarko 2011, p. 21), in which crisis is "a process determined by a series of events and situations synchronized in a certain time span and resulting in dysfunctions of the basic activities of the company" suits the group of definitions of crisis emphasizing its lack of repeatability. The issue of understanding crisis as a process occurring within specific time and resulting from certain unfavourable events is stressed here. That ultimately leads to limiting the efficiency of company operation.

This group of definitions also includes the approach by I.I. Mitroff (2001, p. 5), who presents crisis as a result of the occurrence of unexpected disturbances in a company's operation, including internal and external unpredictable factors. In this case, crisis is perceived as an unexpected phenomenon, resulting, however, from the company's operations. The author claims that if one wants to manage them effectively, special (extra) remedies should be taken (Mitroff 2001, p. 5).

That group also includes the definition by A. Zelek (2003, p. 129), saying that "crisis is understood as the consequence of disturbances in the existence or execution of one or more factors determining the existence and development of a business, both the external ones and internal, dependent on the efficiency of management".

In the processual meaning, crisis is composed of a few stages:

- potential crisis - dangerous to the functioning of the enterprise; unless appropriate actions are taken, it will change into covert crisis,

- covert crisis - manifested in temporary difficulties connected with the 
achievement of goals and division of resources; failure to act for the purpose of eliminating difficulties may lead to the occurrence of overt crisis,

- overt crisis - characterized with clear symptoms dangerous for the efficient functioning of the organization (Urbanowska-Sojkin 1999, p. 29):

- controllable,

- uncontrollable (Krzystek 1980).

The other group of definitions considers crisis from a static perspective. It means that crisis is perceived as a specific state, event or moment in the functioning of the organization. In contrast to considering crisis from the processual (dynamic) perspective, here the cause and effect relationships are not taken into account and the emphasis is rather on the specific situation.

The impact of crisis on the company's situation can be seen in the definition proposed by J. Reid (2000), where crisis is understood as every event which can result in negative consequences and negatively affect the general financial situation of the organization, its relations with recipients and image.

The definition by R.M. Barton (1993, p. 12) belongs to the same trend: he presents crisis as an unpredictable event, often having negative effects and causing lower production, employment, financial results or the organization's image and goodwill. What is interesting in this definition is the expression concerning possible effects of crisis. Crisis may have either positive or negative effects. The least frequent situation is lack of any influence of crisis on company functioning, in other words, neutral effects. Often the positive effects occur along with the negative ones, and the perception of crisis (whether as a positive or a negative phenomenon) will be the result of difference between them. Perceiving crisis as a phenomenon positive and negative at the same time can be observed on the Chinese market, where the term is composed of two words meaning danger and hidden opportunities (chance) (Rakowska 2011, p. 6).

The definition by J.R. Caponigro (2000, p. 5) belongs to the same group of definitions (perceiving crisis as a state). He represents the opinion that crisis is any event or action which may potentially negatively affect the business' credibility and efficiency, and is or will be beyond the business' control. That definition points out events or specific states which can either have a negative influence on the business or be beyond its control. This view is hard to agree with, since in that meaning, every event which may even hypothetically have a negative effect could be referred to as crisis. According to this definition, nearly any situation could be regarded as crisis. It shows a very broad range of interpretations of the phenomenon. 
Another approach to crisis from the perspective of the organization's state is presented by E. Urbanowska-Sojkin (1999, p. 20). Crisis is shown as a pathology of organizational development, lasting for a certain time and making the existence of the enterprise impossible. The author emphasizes that crisis must be considered in all its complexity. Is it not always sufficient to correctly determine its symptoms (signs which allow to recognize crisis), because they comprehensively show the reasons for crisis only to a limited extent.

A similar definition perspective is represented by Z. Płużek and A. Jacyniak (2006, p. 14). According to them, crisis "refers to the moment of uncertainty in the process of personal or social transformation. It is a turning point between one system which is losing its legitimacy, and the other, which is emerging". Applying that definition to an organization, crisis is treated as the turning or critical point in its development.

Also Ch.F. Herman (1963, quoted in: Wawrzyniak 1984, pp. 58-59) perceives crisis from a static perspective. He claims that crisis is a state which threatens the company's survival and accomplishment of its goals. The indicators of crisis may include a threat to the fundamental values of the organization, limited time for taking actions connected with the organization's reaction to the situation and unpredictability of the environment. Crisis can be interpreted as a special decision situation evoking stress in the managers, which results from deterioration of the economic situation and threat to the accomplishment of the organization's basic goals and functions. Ch.F. Herman (1963, quoted in: Wawrzyniak 1984, pp. 58-59) mentions features of crisis such as short decision-making time, surprise and fear resulting from uncertainty (). Emphasizing the unpredictability of the situation and the necessity to make quick decisions are the common features in different definitions of crisis.

The group of definitions showing crisis as a specific state also includes the definition by U. Leupin (1998, p. 39). He emphasises the necessity of third party intervention in order to overcome a crisis. He thinks crisis is displayed in a company through impossibility of accomplishing goals. In order to overcome it, additional people and/or other external forces should be engaged. In this case, crisis is also perceived as a threat to the organization's existence.

The division of definitions of stress into static and dynamic is not disjoint. Some definitions include both elements showing a specific state of the organization and a certain process of successive events. One example of such definitions is the approach proposed by G. Gierszewska (2002, p. 15). According to her, "crisis in a company is a situation or state in which a mass of difficulties results in danger to the execution of fundamental functions of the company, accompanied by 
a limited ability of the organization to eliminate the occurring situation". Failure to notice the dangers and use the occurring market opportunities may not result in any reaction or cause the company's late response to changes. Gradual accumulation of difficulties is characteristic of chronic crises. Their opposite is sudden crises necessitating immediate action.

\section{Approaches to anti-crisis management}

The functioning of a company in a turbulent environment forces it to take actions related to prevention and prediction of crises, and upon their occurrence, to respond quickly. However, the terminology connected with the subject is not straightforward and precise. In subject literature, terms such as ,crisis management' and ,anti-crisis management' are most often found. Yet, these terms are not identical although they refer to a similar subject.

Due to the scope covered by crisis management, a broader and narrower approach can be distinguished. The broad understanding of crisis management includes anticipation (detection of signals, preparation and preventive actions), taking actions in the state of crisis (limitation of losses, restoration of the original state) and the remedial period (drawing conclusions for the future, implementation of changes) (Rydzak 2011, p. 41). In a narrower understanding, crisis management can be treated as taking actions only at the moment of crisis (Coombs 2011, p. 8). It is aimed at combating the occurring threat and limiting the potential negative consequences (Caponigro 2000, s. 16). The narrower understanding of crisis management does not include prevention and preparation for the occurrence of crisis.

The meaning of anti-crisis management is close to more broadly understood crisis management. Some authors use these expressions interchangeably, but it is only possible when the extended definition of crisis management is adopted, including the phases before and after the crisis. Anti-crisis management concentrates on activities taken before the occurrence of crisis, during its course and after its end. It is "a process in which the danger of crisis is predicted, its symptoms and actions limiting the negative effects of crisis are analyzed and its factors are used to continue the development process" (Krzakiewicz 2008, p. 32). Anti-crisis management is a process including four successive phases: prevention of crises, preparation for crises, and organization's reaction to crisis and restoration activities.

The essence of anti-crisis management is not to let the crisis happen. Therefore, the emphasis is put on the first phase, crisis prevention. In that phase, the first 
signals - appearing before the crisis arises - are identified. Quick and effective response to changes both inside the company and in its environment is possible thanks to an early warning system defined as a system of identifying dangers inside and outside the enterprise and providing information in advance, which enables the organization to react (Urbanowska-Sojkin 2002, s. 160). Early warning system allows to (Sikorski 1991, pp. 160-179):

- transfer specific early warning information enabling to predict events inside and outside the organization,

- recognize and eliminate the signs of danger,

- adjust the activities, allowing to reduce the danger and prepare to use the opportunities noticed,

- build competitive advantage.

Early warning system can be described using two key features (UrbanowskaSojkin 2002, s. 163):

- the information process must cover both the changes occurring inside the company and in its environment as well as ensure unlimited information flow,

- the whole system must result from a conscious demand of the company and cover all, even apparently insignificant, phenomena.

The early warning system should not be understood as a separate, additionally introduced, extra management system in a company. It should rather be a component of management systems functioning in the company. It can well be the element of systems such as quality management system or controlling system. It can also be included in management tools and methods such as Balanced Score Card, SWOT analysis of scenario analyses. There is no universal "model" of an early warning system. It should rather be assumed that such a system must be adjusted to the particular organization, checking whether the currently used systems, tools and methods meet the requirements of the anticrisis management idea; they should be improved if needed.

Another approach to anti-crisis management is presented by M. Romanowska (2010; 2012). This approach concentrates on building the company's long-term resistance to crisis. It is related to the positive organizational science (cf. e.g. Zbierowski 2012). In the context of anti-crisis management, it is limited to seeking and formation of the key factors which determine the company's high resistance to crisis (Skalik 2012). The way of achieving it may be among others diversification of the company's operation (risk dispersion) and increasing the company's flexibility, both in the economic meaning (the company's response to uncertainty connected with changes in demand) (Romanowska 2012, p. 131), and the organizational one (the speed of reaction and the level of fit of each element 
of the organization separately and in all of them jointly; Krupski 2008, quoted in: Romanowska 2012, p. 132). The author mentions the following "groups of crisis resistance factors" (Romanowska 2012, pp. 132-134):

- strategic management (the kind of strategic choices concerning the development strategy and competition strategy; the mode of reaction to crisis; methodology of analysis and strategic planning and their impact on crisis resistance),

- resource management (highly flexible and substitutable resources),

- innovativeness of the company (in the sphere of products, processes and "infrastructure": structures of activity, business model, management style etc.),

- structural factors (the organizational structure),

- organizational culture and leadership (the profile and strength of the organizational culture, qualities of the leader and leadership styles),

- management of the company's financial security (application of financial analyses allowing to control the company and changes in its surroundings, using insurances and modern financial supervision tools).

\section{Summary}

It appears that anti-crisis management will be a subject of further research in management literature in the future. In the context of slower growth of the world economy and the occurrence of recession phenomena in many highly developed countries, this problem is more and more significant. Despite the importance of the issue - both for the theory and practice of management - scholars are still not unanimous in such fundamental things as understanding of the term itself. The aim of the authors of this work is to isolate two approaches to anti-crisis management. Depending on the way of understanding crisis, they distinguish: the approach oriented at looking for methods and tools allowing to notice the crisis symptoms early enough, determine its causes and take the appropriate preventive and corrective actions, and the approach based on building company's long-term resistance to crisis (table 1).

Table 1. Approaches to the crisis nature and anti-crisis management - summary

\begin{tabular}{l|l}
\hline Approaches to the crisis nature & Approaches to anti-crisis management \\
\hline $\begin{array}{l}\text { Dynamic perspective - repeatable } \\
\text { cycle }\end{array}$ & $\begin{array}{l}\text { Approach oriented at looking for methods and tools allowing } \\
\text { to notice the crisis symptoms early enough, determine its } \\
\text { causes and take the appropriate preventive and corrective } \\
\text { actions }\end{array}$ \\
\hline
\end{tabular}




\begin{tabular}{l|l} 
State static perspective & $\begin{array}{l}\text { Approach based on building company's long-term resistance } \\
\text { to crisis }\end{array}$ \\
\hline $\begin{array}{l}\text { Dynamic perspective - nob- } \\
\text { repeatable }\end{array}$ & Integrative approach \\
\hline & Source: own study
\end{tabular}

\section{Summary}

Two Faces of Anti-crisis Management: from Definitions to Concepts

Issues related to crisis in business, although present in literature on management for a long time, still remain unexplained to a great extent. Studying the subject literature leads to the conclusion that the concept of anti-crisis management, although present in literature for many years, is understood in a number of different ways. The authors of this article try to systematize approaches to anti-crisis management, starting with approaches and finishing with understanding the very nature (definition) of crisis. They conclude that depending on the way of understanding crisis (its definition), two main approaches to anti-crisis management can be distinguished: one oriented at looking for methods and tools allowing to notice the crisis symptoms early enough, determine its causes and take the appropriate preventive and corrective actions, and one based on building company's long-term resistance to crisis.

Keywords: crisis, anti-crisis management, early warning system, resistance to crisis.

\section{Streszczenie}

Dwa oblicza zarządzania antykryzysowego: od definicji do koncepcji

Zagadnienia związane $\mathrm{z}$ kryzysem $\mathrm{w}$ przedsiębiorstwie, pomimo iż obecne w literaturze dotyczącej zarządzania od dawna, ciągle w dużym stopniu pozostają niewyjaśnione. Studiując literaturę przedmiotu można dojść do wniosku, iż pojęcie zarządzania antykryzysowego, o ile obecne w literaturze od wielu lat, rozumiane jest na klika możliwych sposobów. Autorzy publikacji proponują usystematyzować podejścia do zarządzania antykryzysowego, wychodząc od podejść do zrozumienia samej istoty kryzysu 
(definicji kryzysu). Dochodzą do konkluzji, iż w zależności od sposobu, w jaki rozumie się kryzys (definicji kryzysu), można wyróżnić dwa główne podejścia do zarządzania antykryzysowego: zorientowane na poszukiwanie metod i narzędzi umożliwiających odpowiednio szybkie dostrzeganie symptomów kryzysu, określanie jego przyczyn oraz podejmowanie odpowiednich działań zapobiegawczych i korygujących oraz oparte na budowaniu długotrwałej odporności przedsiębiorstwa na kryzys.

\section{Słowa}

kluczowe: kryzys, zarzadzanie antykryzysowe, system wczesnego ostrzegania, odporność na kryzys.

\section{References}

1. Aplin J. C., Cosier R. A. (1980), Managing creative and maintenance organization, "The Business Quarterly”, spring.

2. Barton R.M. (1993), The Crisis Management, Oxford Press Publishers, Oxford.

3. Bełz G. (2011), System zarzadzania jako regulator odnowy $i$ wzrostu przedsiębiorstw, Wyd. Uniwersytetu Ekonomicznego we Wrocławiu, Wrocław.

4. Caponigro J.R. (2000), The Crisis Counselor. A Step-By-Step Guide to Managing a Business Crisis, Contemporary Books, Lincolnwood, Chicago.

5. Coombs W.T. (2011), Ongoing Crisis Communications: Planning, Managing, and Responding, Sage Publications, Thousand Oaks.

6. Czakon W. (2011), Metodyka systematycznego przegladu literatury, „Przegląd Organizacji", $\mathrm{nr} 3$.

7. Dąbrowski J. (2002/2003), Zmiany strategiczne w teorii i praktyce zarzadzania, Wyższa Szkoła Przedsiębiorczości i Zarządzania im. Leona Koźmińskiego, Warszawa.

8. Davidsson P., Achtenhagen L., Lucia N. (2005), Research on Small Firm Growth: A Review, "European Institute of Small Business", http:// s3.amazonaws.com/academia.edu.documents/30456351/eisb_version_ research_on_small_firm_growth.pdf?AWSAccessKeyId=AKIAJ56TQJR TWSMTNPEA\&Expires=1390141981\&Signature=d9ghIPS2n8VDIo16AJ V\%2BPEYABYU\%3D\&response-content-disposition=inline (10.01.2014 data dostępu)

9. Druker P.F. (1992), Innowacja I przedsiębiorczość. Praktyka i zasady, PWN, Warszawa.

10. Gierszewska G. (2002), Strategie kryzysowe w warunkach globalizacji, w: B. Kozyra, A. Zelek (red.), Praktyka zarzadzania kryzysem w przedsiębiorstwie, Wyd. Zachodniopomiorskiej Szkoły Biznesu, Szczecin. 
11. Greiner L. E. (1998), Evolution and revolution as organizations grow, "Harvard Business Review", May-June.

12. Gryz J., Kitler W. (red.) (2007), System reagowania kryzysowego, Wyd. Adam Marszałek, Toruń.

13. Hanks S. H., Watson C. J., Jansen E., Chandler, G. N. (1994), Tightening the life-cycle construct: A taxonomic study of growth stage configurations in hightechnology organizations, "Entrepreneurship Theory and Practice”, Vol. 18, No. 2.

14. Herman Ch.F. (1963), Some Consequences of Crisis Which Limit the Viability of Organizations, "Administrative Science Quartely", No 8.

15. Kazanjian R. K., Drazin R. (1989), An empirical test of a stage of growth progression model, „Management Science”, Vol. 35, No. 12.

16. Kral Z., Zabłocka-Kluczka A. (2003), Istota zjawisk kryzysowych, w: J. Skalik (red.), Zachowania organizacji wobec zjawisk kryzysowych, Cornetis, Wrocław.

17. Krzakiewicz K. (2008), Zarzadzanie antykryzysowe w organizacji, Wyd. Akademii Ekonomicznej w Poznaniu, Poznań.

18. Krzystek M. (1980), Organisatorische Möglichkeiten des Krisenmanagements, "Zeitschrift für Organisation", nr 2.

19. Leupin U. (1998), Turnaround von Unternehmen: von der Krisenbewältigung zur Erfolgssteigerung, ein praktischer Führungsbehelf für Unternehmen, Banken und Berater, Bern Paul Haupt, Bern- Stittgart- Wieden.

20. Levie, J.D., Lichtenstein B. (2010), A terminal assessment of stages theory: introducing a dynamic states approach to entrepreneurship, "Entrepreneurship Theory and Practice", Vol. 34, No. 2.

21. Łuczak M. (2003), Ryzyko i kryzys w zarządzaniu przedsiębiorstwem, Wyższa Szkoła Ekonomiczna, Warszawa.

22. Murdoch A. (2003), Komunikowanie w kryzysie - jak ratować wizerunek firmy, Poltext, Warszawa.

23. Mitroff I.I. (2001), Managing crisises before they happen, American Management Association, New York.

24. Oldcorn R. (1989), Management, MacMillan, London.

25. Phelps R., Adams R., Bessant J. (2007), Life cycles of growing organizations: A review with implications for knowledge and learning, "International Journal of Management Reviews", Vol. 9, No. 1.

26. Płużek Z., Jacyniak A. (2006), Świat ludzkich kryzysów, Wyd. WAM, Kraków.

27. Rakowska A. (2011), Kryzysowe przywództwo, czyli kompetencje menedżerskie niezbędne w trudnych czasach, "Organizacja i Zarządzanie", nr 2.

28. Reid J. (2000), Crisis Management: Plannind and media Relations for The Design and Construction Industry, John Wiley\&Sons Inc., New York.

29. Romanowska M. (2010), Przełomy strategiczne w przedsiębiorstwie, Studia i Prace Kolegium Zarządzania i Finansów, Zeszyt Naukowy nr 98, SGH, Warszawa.

Two Faces of Anti-crisis Management: from Definitions to Concepts 
30. Romanowska M. (2012), Uwarunkowania odporności przedsiębiorstw na kryzys makroekonomiczny. Propozycja podejścia badawczego, w: A. Barabasz, G. Bełz (red.), Systemy i procesy zmian w zarządzaniu, Wyd. Uniwersytetu Ekonomicznego we Wrocławiu, Wrocław.

31. Rydzak W. (2011), Reputacja a działania informacyjne organizacji w sytuacjach kryzysowych i determinanty ich wyboru, Wyd. Uniwersytetu Ekonomicznego w Poznaniu, Poznań.

32. Sikorski A. (1991), Systemy wczesnego ostrzegania, w: K. Fabińska, J. Rokita (1991), Rozwój przedsiębiorstwa. Procesy u strategie rozwoju, Wyd. Akademii Ekonomicznej im K. Adamieckiego w Katowicach, Katowice

33. Słownik wyrazów obcych (2000), Wydawnictwo NaukowePWN, Warszawa

34. Skalik J. (2012), Aktywizacja potencjatu rozwojowego przedsiębiorstwa, w: A. Stabryła, K. Woźniak (red.), Determinanty potencjału rozwoju organizacji, Wyd. Mfiles, Kraków Stownik wyrazów obcych (2000), Wydawnictwo Naukowe PWN, Warszawa.

35. Steinmetz L. (1969), Critical stages of small business growth: when they occur and how to survive them, "Business Horizons", Vol. 12, No. 1.

36. Urbanowska-Sojkin E. (1999), Zarzadzanie przedsiębiorstwem. Od kryzysu do sukcesu, Wyd. Akademii Ekonomicznej w Poznaniu, Poznań.

37. Urbanowska-Sojkin E. (2002), Antycypowanie kryzysów przedsiębiorstwa - aspekt informacyjny, w: B. Kozyra, A. Zelek (red), Praktyka zarzadzania kryzysem w przedsiębiorstwie, Wyd. Zachodniopomorskiej Szkoły Biznesu, Szczecin.

38. Walas-Trębacz J., Ziarko J. (2011), Podstawy zarządzania kryzysowego. Część 2, Zarządzanie kryzysowe w przedsiębiorstwie, Oficyna Wydawnicza AFM, Kraków.

39. Wawrzyniak B. (1984), Zarządzanie w kryzysie, PWE, Warszawa.

40. Wieczerzyńska B. (2009), Kryzys w przedsiębiorstwie, CeDeWu Wydawnictwo Fachowe, Warszawa.

41. Wróblewski R. (2010), Wybrane problemy zarządzania przedsiębiorstwem w sytuacjach kryzysowych, Zeszyty Naukowe Uniwersytetu PrzyrodniczoHumanistycznego w Siedlcach, Nr 87 Seria: Administracja i Zarządzanie, Siedlce

42. Zbierowski P. (2012) Orientacja pozytywna organizacji wysokiej efektywności, Wyd. Oficyna Wolters Kluwer, Warszawa

43. Zelek A. (2003), Zarzadzanie kryzysem w przedsiębiorstwie. Perspektywa strategiczna., Instytut Organizacji Zarządzania w Przemyśle „ORGMASZ”, Warszawa.

44. Zimniewicz K. (1990), Nauka o organizacji i zarzadzaniu, PWN, Warszawa - Poznań.

Project was funded by the National Science Center awarded on the basis of the decision no. DEC-2011/01/B/HS4/06543 